\title{
Analisis Kebutuhan Pengembangan Organisasi Pada Kelompok Usaha X (Pendekatan 7s Framework Of Mckinsey)
}

\author{
Didik Widiantoro', Yanwar Arief', Irfani Rizal' ${ }^{3}$, Wina Diana Sari ${ }^{4}$, Rino \\ Gohensen $^{5}$
}

Fakultas Psikologi

Universitas Islam Riau

12didikwidiantoro@psy.uir.ac.id

\begin{abstract}
The development of the era of globalization has made the competition between the business and industrial worlds increasing rapidly. Business $X$ is a small and medium enterprise (SME) which was established to develop the skills and economy of the group from Business $X$, in the end, Business $X$ was successfully established in 2020. One of the effective methods that can be done to see the effectiveness of Business $X$ is to use 7s Mc analysis. Kinsey. The purpose of this research is to evaluate the effectiveness of Business $X$ 's performance and to analyze the development needs of Business $X$ Based of the result of the assessment and analysis conducted. The main method used in qualitative descriptive with observation and interviews as data collection methods. Based of the result of the assessment obtained, it shows that the setting of unclear goals/targets in Business $X$ and development related to the individual skills of Business $X$ members. Therefore, Business $X$ requires training/psychoeducation in the form of Goal Setting Training so that members can further improve their performance in achieving the goals set. clear and precise.
\end{abstract}

Keyword : Analysis, 7s Mc Kinsey

\begin{abstract}
Abstrak
Perkembangan era globalisasi menjadikan persaiangan dunia usaha dan industri semakin meningkat pesat. Usaha $\mathrm{X}$ termasuk kedalam usaha mandiri yang didirikan dengan tujuan mengembangan keterampilan serta perekonomian kelompok dari Usaha X, pada akhirnya Usaha X ini berhasil didirikan pada tahun 2020. Salah satu metode efektif yang dapat dilakukan untuk melihat efektivitas Usaha $\mathrm{X}$ adalah dengan menggunakan analisis $7 \mathrm{~s}$ Mc Kinsey. Tujuan dari pelaksanaan penelitian ini ialah untuk Mengevaluasi efektivitas kinerja Usaha X dan Menganalisa kebutuhan pengembangan Usaha $\mathrm{X}$ berdasarkan hasil asesmen dan analisis yang dilakukan. Metode utama yang digunakan dalam deksriftif kualitatif dengan observasi dan wawancara yang menjadi metode pengumpulan data. Berpedoman dari hasil yang diperoleh memperlihatkan sasaran yang ditentukan pada awal untuk pengembangan terkait keterampilan individu sebagai pengurus usaha X belum jelas. Oleh sebab itu, Goal Setting Training dibutuhkan
\end{abstract}


untuk psikoedukasi/pelatihan dalam usaha $\mathrm{X}$ untuk peningkatan kinerja untuk mencapai tujuan yang tepat dan jelas.

Kata kunci: Analisis, 7s Mc Kinsey

\section{Pendahuluan}

Kelompok termasuk elemen vital dalam berorganisasi. Jex (2002) mengungkapkan bahawa kelompok dalam kehidupan berorganisasi diperlukan untuk dapat memenuhi berbagai tugas serta kelompok juga sebagai landasan dasar untuk berkembangnya suatu organisasi. Kelompok menurut Katzenbach dan Smith merupakan sekumpulan individu yang memiliki kesamaan tujuan, mempunyai kesetaraan metode bekerja, serta memiliki tanggung jawab antara satu dengan yang lainnya (McLean, 2006).

Efektivitas dalam suatu kelompok sangat diperlukan, baik dalam kualitas kerja maupun dalam hal kinerja. Dimana performance organisasi dapat dipengaruhi oleh efektivitas kelompok. Harapan organisasi yaitu memiliki Efektivitas yang tinggi pada kelompok. Apabila efektivitas tercapai, maka hal tersebut mempermudah organisasi dalam mewujudkan tujuan. Banyak organisasi yang tidak mampu bertahan lama disebabkan kurangnya kemampuan manajemen dalam mengelola kelompok dan sistem perusahaan/organisasi.

Dalam rangka mengikuti perkembangan maka perlu dilakukannya peningkatan efektivitas kelompok serta pengembangan pada kelompok, hal tersebut dilakukan agar dapat menjalankan tuntutan kerja yang dinamis. Sehingga, dibutuhkan asesmen atau pengukuran guna mengetahui bagaimana kelompok tersebut efektif baik dalam hal kualitas kerja maupum kinerja pada suatu divisi. Asesmen juga membantu dalam menentukan pengembangan yang tepat guna peningkatan efektivitas dan kualitas kelompok. Kelompok dinilai efektif ketika mampu mencapai tujuan yang tepat, memiliki struktur pembagian tugas serta alur kerja yang sistematis, anggota kelompok mempunyai kompetensi yang memenuhi standar, mempunyai aturan, serta mempunyai kinerja berdasarkan nilai budaya dan 
juga mempunyai peran dan fungsi yang jelas dalam suatu kelompok (Cumming, 2005).

Perwujudan tujuan atau visi dalam organisasi memerlukan adanya kolaborasi antar anggota maupun tim. Kelompok dalam suatu tim merupakan kumpulan orang yang bersemangat dalam mencapi tujuan yang telah disepakati bersama.

Peningkatan kapasitas organisasi merupakan serangkaian proses atau cara dalam meningkatkan keterampilan organisasi agar semua bagian dan aspek didalam organisasi secara berkala menjadi lebih efisien dan efektif. Menurut Ivancevich, dkk. (2007) Hal tersebut akan terwujud secara baik dan optimal dengan rutin melakukan evaluasi dan asesmen untuk mengetahui bagaimana peningkatan atau perkembangan dalam organisasi.

Usaha X dapat dikategorikan sebagai kelompok ataupun sebagai organisasi, hal tersebut dilatarbelakangi karena anggota didalamnya mempunyai persamaan visi dan misi dalam mewujudkan suatu tujuan. Selain itu, usaha $\mathrm{X}$ dapat dikategorikan sebagai usaha kecil menegah (UKM) yang berdiri dengan tujuan untuk memperluas keterampilan serta perekonomian kelompok Usaha $\mathrm{X}$, pada tahun 2020 akhirnya Usaha X berhasil dibangun. Usaha ini yakni usaha waralaba yang memiliki beberapa cabang usaha antara lain restaurant, apotek dan fitness.

Dalam pelaksanaan usaha $\mathrm{X}$ belum memiliki tujuan yang jelas. Hal tersebut dibenarkan oleh karyawan yang mengaku bahwa usaha $\mathrm{X}$ ini dalam menjalankan aktivitas tidak memiliki target yang jelas. Menurut Cumming (2007) menyebutkan bahwa jika didalam suatu kelompok tidak memiliki goal clarity atau sebuah sasaran dalam mecapai keberhasilan usaha maka kelompok tidak akan dapat bekerja secara efektif. Oleh sebab itu, diperlukan upaya lanjutan agar mampu memperoleh segala informasi yang berhubungan dengan setiap masalah yang terjadi hingga diketahui dan didapatkan kesimpulan mengenai pengembangan dan perubahan yang dilakukan selanjutnya. Pengembangan kelompok perlu dilakukan untuk peningkatan efektivitas kelompok. Hal tersebut dilakukan karena adanya tekanan tugas oleh atasan untuk peningkatan kepercayaan atasan pada anggota kelompok, 
selain itu tekanan dunia kerja yang terjadi secara dinamis membuat kelompok harus beradaptasi dengan perkembangan.

Berdasarkan hal tersebut maka asesmen atau pengukuran sangat perlu dilakukan untuk mengetahui seberapa jauh kelompok tersebut bekerja secara efektif baik dari segi kualitas kerja maupun kinerja dalam divisi tersebut, serta membantu dalam menentukan cara pengembangan yang tepat untuk meningkatkan efektivitas dan kualitas dalam kelompok. Pelaksanaan asesmen pada Usaha X dilaksanakan dengan tiga level analisis yaitu analisis organisasi, analisis pekerjaan/tugas, dan analisis individual. Organizational analysis dengan menerapkan metode wawancara dan observasi.

Pelaksanaan asesmen diberbagai aspek bertujuan untuk mengetahui kebutuhan serta efektivitas dalam kelompok tersebut. Oleh sebab itu, pengukuran atau asesmen yang dilaksanakan pada usaha X di Pekanbaru Riau harus dilaksanakan untuk mengukur efektivitas dan pemberian saran yang tepat dan terarah dalam rangka pengembangan.

\section{Analisis 7S Framework of McKinsey}

Model 7S Framework of McKinsey merupakan suatu metode yang dikembangkan oleh Mc.Kinsey pada awal 1970 dengan memiliki tujuan dalam membantu perusahaan melakukan analisi dan rencana dalam menghadapi suatu perubahan. Sehingga masalah yang timbul dapat didiagnosa dan dapat diberikan perlakuan atau tindakan yang sesuai dengan permasalahan.

Diagnosis organisasi dilakukan dengan 7S Framework of McKinsey digunakan untuk mengetahui efektivitas organisasi berikut faktor-faktor yang mempengaruhinya. Dalam teori 7-S McKinsey, Stucture, Strategi, Systems, Shared Values, Skills, Staf, \& Style. Adapun penjelasannya sebagai beikut:

1. Shared Values; Merupakan nilai budaya dalam bekerja pada organisasi. Dan merupakan guideline bagi para anggota organisasi sebagai acuan untuk tumbuh dan berkembang.

2. Structure; struktur organisasi (organizational structure) adalah cerminan dari shared values organisasi dalam upaya pencapaian sasaran 
dan tujuan organisasi secara optimal. Struktur yang sanggup mencerminkan shared values dengan baik akan memberdayakan organisasi untuk mencapai sasaran dan tujuan tersebut.

3. System; sistem yang dikembangkan organisasi juga bersumber pada shared values yang ada. Sistem ini termasuk berbagai hal yang menyangkut perencanaan, implementasi, kontrol dan evaluasi, anggaran, dan penghargaan.

4. Staff; berdasarkan shared values yang ada, organisasi membentuk personil di dalamnya (pengelola). Organisasi akan menentukan prasyarat orang-orang seperti apa yang dianggap sesuai dengan keberadaan dan tujuan organisasi. Sebagaimana diketahui, jika tujuan organisasi dan tujuan individu di dalamnya tidak searah, maka akan sangat sulit bagi organisasi tersebut untuk dapat tumbuh dan berkembang dengan baik.

5. Skills; dalam organisaasi, keterampilan individu sangat berperan penting secara efektif untuk meningkatkan keberhasilan pencapaian tujuan. Jika ketrampilan para pelaksana organisasi kurang sesuai dengan kebutuhan organisasi tersebut untuk mewujudkan visinya, maka organisasi tersebut akan cenderung kontraproduktif. Oleh karenanya, skills merupakan cerminan dari core competence organisasi, karena strategi yang disusun juga merupakan refleksi atas skills yang ada.

6. Style; gaya manajemen (kepemimpinan) organisasi merupakan hasil perpaduan antara kelima elemen sebelumnya. Kelima elemen di atasa menentukan bagaimana gaya kepemimpinan yang tepat dalam mencapai sasaran dan tujuan organisasi. gaya kepemimpinan yang kurang tepat dapat membuat kegagalan serta menuju sebuah kehacuran.

7. Strategy; Strategi organisasi disebutkan sebagai suatu sasaran yang tepat mengenai petunjuk digunakan dalam mencapai tujuan dan sasaran organisasi. 


\section{Metode Penelitian}

Penelitian ini menggunakan pendekatan kualitatif dengan pendekatan studi kasus. Menurut Bodgan dan Tailor (dalam Moleong, 2007) mengatakan bahwa penelitian kualitatif ini akan menghasilkan data deskriptif yang berupa penjelasan tertulis atau lisan dari orang-orang yang diamati. Penelitian kualitatif ini bersifat alamiah, tidak melakukan perencanaan baik dengan keadaan ataupun lingkungan penelitian. Namun melakukan penelitian terhadap suatu keadaan tanpa rekayasa. Penelitian ini juga scara sengaja melihat dan membiarkan kondisi yang diteliti berada dalam keadaan yang sebenarnya.

Pelaksanaan asesmen menggunakan beberapa metode pengumpulan data, seperti observasi dan wawancara. Moleong (2000), percakapan yang terjadi dengan tujuan tertentu disebut wawancara yang terjadi antara dua yakni interviewer (pewawancara) yang memberi pertanyaan dan interviewee (yang diwawancarai) atau orang yang menjawab pertanyaan yang diberikan. Lincoln dan Guba (Moleong, 2000) meyebutkan tujuan diadakannya wawancara antara lain menginterpretasi seseorang, peristiwa, kegiatan, tuntutan, antara lain; melakukan kontruksi kebulatan yang dilalui pada masa lampau.

Hadi (Novianti, 2010) menyebutkan observasi adalah metode penelitian sengaja, sistematis, dengan indera yang mampu merangkum kejadian yang sedang terjadi atau berlangsung. Sedangkan Cartwright dan Cartwright (Pratiwi, 2010) menyebutkan bahwa observasi merupakan proses pengamatan dan pencatatan informasi tentang perilaku secara sistematis dengan tujuan membuat keputusan. Selain itu, Warner dan Maurer (Novianti, 2010) merumuskan bahwa observasi merupakan metode pengumpulan segala informasi secara sistematis.

Data yang dikumpulkan dari wawancara dan observasi dianalisis menggunakan metode triangulasi. Metode ini digunakan untuk mempertegas bahwa untuk memulai tahapan konteks menganalisis keseluruhan data diawali dengan melakukan metode pengumpulan data, reduksi data, menyajikan data, serta kesimpulan-kesimpulan.

Teknik analisa data merupakan metode dalam mengubah data untuk menjadi sebah informasi yang dibutuhkan. Teknik analisis data sangat penting 
dilakukan dalam proses penelitian agar mudah untuk peneliti menganalisis sebuah data. Data kualitatif dikumpulkan dengan teknik analisisnya juga menggunakan teknik kualitatif sehingga menghasilkan data kualitatif. Analisis kualitatif berarti pengintrepretasiannya menggunakan nalar dan logika yang sistematis. Analisis yang digunakan adalah model analisis kualitatif, yakni dengan menggunakan model analisis yang terdiri dari tiga komponen yaitu reduksi data, sajian data, dan penarikan kesimpulan dengan cara interactive model milik Miles dan Huberman dalam Sugiyono (2013). (a) Reduksi Data, mereduksi data adalah langkah dalam memilah bagian-bagian penting serta merangkum hal pokok dari sebuah sumber data (Sugiyono, 2014). Mereduksi data akan membantu peneliti dalam melakukan proses pengumpulan data dengan memberikan gambaran yang jelas. Dalam melakukan reduksi akan diredukti secara terus menerus selama pelaksanaan penelitian, bahkan dari peneliti pengumpulan data dilakukan sampai penelitian berahir. Dalam penelitian ini, peneliti mereduksi data dengan cara pengkodean (coding), yaitu dengan memberikan kode-kode pada bagian-bagian penting dari sebuah sumber data yang dianggap penting. (b) Penyajian Data, penyajian data dalam Penelitian kualitatif dilakukan dalam bentuk uraian singkat, bagan, ataupun tabel hubungan antar kategori atau sejenisnya (Sugiyono, 2014). Sajian ini merupakan kalimat yang disusun secara logis dan sistematis, sehingga bila dibaca akan bisa mudah dipahami berbagai hal yang terjadi dan memungkinkan peneliti untuk membuat analisis ataupun tindakan lain berdasarkan pemahamannya tersebut. Sajian data ini harus mengacu pada rumusan masalah yang telah dirumuskan sebagai pertanyaan penelitian. (c) Penarikan Kesimpulan, kesimpulan disini merupakan temuan baru dan belum pernah ada yang berupa kalimat yang diambil dari sebuah ide pemikiran.

\section{Hasil dan Pembahasan}

Melalui proses asesmen yang telah dilakukan dengan menggunakan wawancara kepada subjek penelitian. Intrumen wawancara berdasarkan pendekatan 7s Mckinsey, selanjutnya peneliti memformulasikan ke dalam tiga level yaitu level 
organisasi, pekerjaan dan individu, dan didapatkan hasil analisa kebutuhan yakni sebagai berikut:

\section{Analisis Organisasi}

Hasil asesmen wawancara dan observasi yang diperoleh menunjukkan terdapat tujuan yang jelas dalam menjalankan usaha, ini tergambar dari perencanaan yang sangat terencana dalam menjalankan usaha. Begitu juga dengan shared values terkait visi dan misi Usaha $X$, usaha $X$ memiliki tujuan untuk berkembang dan bermanfaat bagi banyak orang, dimana Usaha $\mathrm{X}$ ini memiliki system kepada karyawannya untuk kerja hanya 2 tahun dan setelah itu diminta untuk berkembang sendiri, hal ini disampaikan subjek AP :

"Pertama, tujuan dari usaha ini ya ini, kita ingin usaha kita ini berkembang, dikenal banyak orang, dan kemudian bermanfaat bagi banyak orang” (WS1, 2526)

"Misinya apa, ya salah satunya ya dengan membuka usaha tapi diluar itu berkah Indragiri ini bergerak emang kita lebih memberdayakan ke karyawan itu sebetulnya. Karena setiap karyawan yang masuk ke kita itu Cuma kasih batas waktu 2 tahun. Nah kasih batas waktu 2 tahun dan kemudian setelah 2 tahun itu mereka harus berkembang, "(WS1,31-35)

Mengenai skill atau kemampuan anggota yang cukup pandai atau memadai dalam melakukan setiap pekerjaan, dimana seluruh proses pembuatan dari awal hingga akhi harus diketahui oleh anggota. Hal ini dilatarbelakangi agar seluruh anggota sudah melakukan masing-masing tanggung jawab sesuai dengan tugas yang telah ditetapkan manajemen. Subjek AP menjelaskan:

\footnotetext{
"Nah makanya karyawan kita bayar mahal tapi dengan syarat mereka bertanggung jawab terhadap ini jobdesc mereka...” (WS1, 60-63).

“Biasanya diberikan pelatihan sebelum masuk kerja mbak....” (WW, 6 )

Style Usaha $\mathrm{X}$ terkait manajemen pemasaran cenderung berfokus pada pelayanan yang diberikan, dimana manajemen Usaha $\mathrm{X}$ memandang pelayanan kepuasan yang diberikan kepada konsumen merupakan kunci kesuksesan dalam berhasil atau berkembang. Subek AP menjelaskan:
} 
"Ketika ini nanti mampu kita jaga, konsisten kita disini, nah ini akan menjadi senjata kita lah, anak panah kita untuk buat marketing. Untuk menggaet banyak orang lagi." (WAP, 69-72)

Dalam hal Strategy, manajemen Usaha $\mathrm{X}$ menyampaikan masih memikirkan strategi yang tepat terkait masalah branding Usaha X. Setelah 2 tahun berajalan, manajemen merasa dapat memperluas jangkauan pasar, sehingga membutuhkan branding yang kuat agar bisa bersaing dengan competitor lainnya. Subek W menuyampaikan:

"Nah, jadi PR kami untuk saat ini yak an, itu yang pertama system kemudian branding. Nah kalo system dan branding ini sudah mantap, artinya sudah selesai,...." (WW, 1$)$

\section{Analisis Pekerjaan/tugas}

Berdasarkan data yang diperoleh melalui wawancara bahwa pekerjaan yang telah dilaksanakan sudah sesuasi dengan tanggung jawab karyawan masing-masing. Terkait keterampilan pada pengetahuan anggota usaha $\mathrm{X}$ tergolong baik serta selalu diberikan pembinaan dari pihak manajemen Usaha X.

\section{Analisis Individu}

Hasil wawancara didapati adanya kesulitan yang dialami oleh anggota usaha $\mathrm{X}$ yaitu berkaitan dengan kemampuan melayani pelanggan, dimana seorang anggota sempat membagikan kisah terkait dengan keterampilan melayani, anggota tersebut mendapat teguran oleh manajemen karena kurang maksimal dalam melayani konsumen. Pihak manajemen langsung memberikan pendampingan kepada karyawan tersebut.

\section{Pembahasan}

Dilatarbelakangi dengan hasil asesmen yang diperoleh dengan menggunakan metode wawancara dan observasi pada tiga level yakni, organisasi, tugas dan individu dapat peneliti menyimpulkan bahwa permasalah yang terjadi dalam Usaha $\mathrm{X}$ adalah pada level organisasi yang mana organisasi/Usaha $\mathrm{X}$ belum 
memiliki tujuan yang jelas dalam menjalankan Usaha X. Sehingga pada level tugas dan individu menjadi tidak muncul permasalahan yang signifikan.

Permasalahan yang terjadi berdasarkan analisa organisasi yang dilakukan terletak pada strategy mengenai penetapan sasaran serta tujuan organisasi. Dengan memiliki visi dan misi dari usaha $X$ yang jelas, seharusnya Usaha $X$ sudah memiliki arah yang jelas terkait gambaran besar ke depannya, sehingga memberi dampak pada strategi yang kuat dan struktur organisasi yang baik. Hal tersebut nantinya dapat mempengaruhi sistem yang berkaitan dengan perencanaan dan style manajeman, serta berdampak pada pada staff dan skill. Dalam Cumming (2005), keefektivitasan kelompok dalam organisasi salah satunya dipengaruhi oleh tujuan dan sasaran yang jelas. Sedangkan analisis tugas yang dilakukan menemukan sudah terdapat pembagian pekerjaan yang jelas pada setiap anggota, kemampuan dan keterampilan yang memadai pada setiap anggota. Selain itu, hal yang belum terungkap dalam analisis individu adalah terkait kendala yang dilalui, hanya kendala keterampilan yang dimiliki salah seorang anggota di luar keterampilan produksi usaha X. Hasil analisa tersebut dapat disimpulkan bahwa permasalahan yang terjadi disebabkan oleh:

1. Minimnya sasaran dan tujuan usaha $X$ mengenai pengembangan usaha.

2. Kemampuan serta keterampilan yang dibutuhkan dipertahankan dan kembangkan.

Dilatarbelakangi dengan analisis organisasi, analisis tugas, dan analisis individu yang telah dilakukan, maka dapat ditarik kesimpulan bahwa usaha $\mathrm{X}$ membutuhkan sosialisasi dan psikoedukasi terkait dengan goal setting untuk memberi gambaran atau saran dalam memajukan serta mengatasi kendala yang dialami.

Saran dari peneliti adalah dengan pemberian intervensi Goal setting mampu membantu anggota mempunyai gambaran ke depan mengenai pengembangan usaha yang ingin dicapai. Hal ini mampu membuat anggota menentukan langkahlangkah dalam mencapai tujuan yang telah ditentukan. Tujuan nya berdasarkan kepentingan bersama yang sudah ditentukan bersama oleh anggota dalam usaha tersebut, sehingga nantinya mereka mampu menjalankan tanggung jawabnya 
sebagai anggota usaha dan memiliki komitmen untuk merealisasikan tujuan demi kemajuan usaha itu sendiri.

\section{Kesimpulan}

Berdasarkan hasil asesmen yang telah dilakukan menunjukkan bahwa usaha $\mathrm{X}$ belum menetapkan secara jelas tujuan/sasaran dalam pengembangan terkait keterampilan individu anggota usaha X. Oleh sebab itu, usaha X perlu melakukan pelatihan/psikoedukasi berupa Goal Setting Training agar terjadi peningkatan kinerja anggota dalam mencapai tujuan yang jelas dan tepat.

\section{Daftar Pustaka}

Brown, D.R \& Harvey, D. 2006. An Experiential Approach to Organization Development, SeventhEdition. Canada: Prentice Hall.

Cumming, T.G \& Worley, C.G. Organization development and Change. Southwestern:Thomas

Ivancevich, dkk. 2007. Organiational Behavior and Management. Jakarta: Erlangga.

Kirkpatrick, D. 1994. Evaluating Training Programs-The Four Level. Berret Koehler Publisher.Inc.

Kreitner, R \& Kinicki, A. 2001. Organization Behavior, 5 th Edition. New York: Irwin McGraw-Hill.

McLean, G.N. Organization Development. San Francisco: Berrett Koehler Publishers, Inc.

Moleong, L.J. 2005. Metodologi Penelitian Kualitatif, Edisi Revisi. Bandung: PT. Remaja Rosdakarya.

Novianti, N.P. 2010. Modul Kuliah Observasi dan Wawancara (Tidak Diterbitkan). Yogyakarta: Fakultas Psikologi dan Ilmu Sosial Budaya Universitas Islam Indonesia.

Riggio, R.E. 2003. Introduction to Industrial/Organizational Psychology. New Jersey: Prentice Hall. 
Sarwono, J. 2010. Pintar Menulis Karya Ilmiah: Kunci Sukses dalam Menulis Ilmiah. Yogyakarta: Penerbit Andi.

Siagian, S.P. 2002. Kiat Meningkatkan Produktivitas Kerja. Jakarta: Rineka Cipta.

Simmamora, H. 2006. Manajemen Sumber Daya Manusia. Yogyakarta:STIE YKPN.

Triner, D., Greenberry, A \& Watkins, R. 1996. Training Needs Assessment: A Contradiction in Terms. New Jersey: Educational Technology.

Umar, H. 2006. Metode Riset Bisnis. Jakarta: Gramedia. 